\title{
Analisis Faktor yang Mempengaruhi Non Performing Loan pada Bank Perkreditan Rakyat di Nusa Tenggara Barat
}

\author{
Yati Fitria Zamri ${ }^{1}$ \\ Fakultas Ekonomi dan Bisnis \\ Universitas Mataram, Indonesia \\ Email: yati.fitria@gmail.com
}

\author{
Lilik Handajani ${ }^{2}$ \\ Fakultas Ekonomi dan Bisnis \\ Universitas Mataram, Indonesia
}

\author{
Ahmad Rifai ${ }^{3}$ \\ Fakultas Ekonomi dan Bisnis \\ Universitas Mataram, Indonesia
}

\begin{abstract}
ABSTRAK
Penelitian ini bertujuan untuk memberikan bukti empiris mengenai penyebab utama tingginya Non Performing Loan (NPL) pada BPR di Propinsi Nusa Tenggara Barat. Metode penelitian yang diguanakan analisis faktor exploratory. Populasi adalah seluruh BPR di Nusa Tenggara Barat. Responden terdiri dari direksi, bagian marketing dan bagian penagihan pada BPR. Berdasarkan hasil penelitian terdahulu didapatkan sebanyak 38 variabel penyebab NPL BPR. Berdasarkan analisis faktor exploratory ditemukan 10 faktor utama sebagai peny eba $b$ u tama tingginya NPL pada BPR di Nusa Tenggara Barat. Hasil penelitian ini da pat dijadikan acuan bagi BPRdalam upaya menekan ju mlah NPL pada masing-masing BPR. Selainitu dapat dija dikan acuan bagi Otoritas Jasa Keuangan dalam rangka pen gaw asan kepa da institusi BPR.
\end{abstract}

Kata Kunci: Non Performing Loan; Bank Perkreditan Rakyat; Analisis Faktor Exploratory; Faktor Utama.

\section{Analysis Factors Affecting Non Performing Loan at Rural Bank in West Nusa Tenggara}

\section{ABSTRACT}

This study aims to provide empirical evidence about main cause of height Non Performing Loan (NPL) at Rural Bank in West Nusa Tenggara. The methodology used is Factor Analysis exploratory. Population in this research is all Rural Bank in West Nusa Tenggara. Total Respondent are 128 respondent which are Board Director, Marketing department, and Collection Department. Based on previous research found 38 variabel that causes NPL at Rural Bank. By using analysis factor the study found 10 major factors as the main cause of the NPL at Rural Bank in West Nusa Tenggara. The results of this research can be used as a reference for Rural Bank in an attempt to suppress the NPL in each Rural Bank. In addition, it can be used as a reference for financial Services Authority (OJK) in the surveillance institution to BPR.

Keywords: $\quad$ Non Performing Loan; Rural Bank; Factors Analysis; Mainfactor.

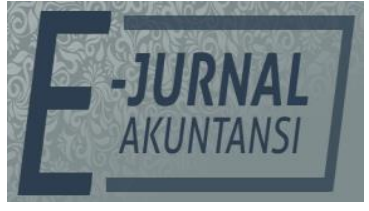

E-JA

e-Jurnal Akuntansi e-ISSN 2302-8556

Vol. 30 No. 4

Denpasar, April 2020

Hal. 815-814

Artikel Masuk:

5 Desember 2019

Tanggal Diterima:

14 Februari 2020 


\section{PENDAHULUAN}

Bank Perkreditan Rakyat (BPR) adalah bank yang melaksanakan kegiatan usaha secara konvensional atau berdasarkan prinsip sharia. Kegiatan utama yang dapat dilakukan oleh Bank Perkreditan Rakyat adalah: Menghimpun dana dari masyarakat dalam bentuk simpanan berupa deposito berjangka, tabungan, $\mathrm{d}$ an atau bentuk lainnya yang dipersamakan dengan itu, (www.ojk.go.id). Pada mulanya tugas pokok BPR diarahkan untuk menunjang pertumbuhan dan modernisasi ekonomi perdesaan serta mengurangi praktikijon dan para pelepas uang (rentenir). Namun demikian, peran Bank Perkreditan Rakyat semakin penting sebagai penyedia sumber pendanaan dan penggerak roda perekonomian di daerah (Herri., 2008).

BPR merupakan mediator antara pemilik dana dan pihak yang memerlukan dana. BPR menyalurkan kredit/pembiayaan ke masyarakat dalam bentuk pinjaman yang tidak terlepas dari berbagai risiko diantaranya risiko tidak tertagihnya kredit yang disebut kredit bermasalah atau Non Performing loan $(N P L)$. Angka NPL yang tinggi pada suatu perbankan akan berpengaruh pada likuiditas, solvabilitas, profitabilitas, bonafiditas, tingkat kesehatan bank dan modal kerja (Mahmudah, 2013). Permasalahan Non Performing Loan (NPL) juga dialami oleh BPR di Nusa Tengara Barat yang memiliki 32 BPR dan BPRS. Per 30 September 2019, hanya 5 BPR/BPRS diantaranya yang memiliki NPL dibawah $5 \%$. Sisanya sebanyak 27 BPR memiliki NPL diatas 5\% (www.ojk.go.id). Ratarata NPL BPR di Propinsi Nusa Tenggara Barat sebesar 10.67\%. Berikut adalah gambaran rata-rata NPL BPR di Nusa Tenggara Barat dalam 4 tahun terakhir.

Tabel 1. NPL BPR di Propinsi NTB Periode 2015 Sampai Dengan September 2019

\begin{tabular}{llllll}
\hline Keterangan & Sep 2019 & Des 2018 & Des 2017 & Des 2016 & Des 2015 \\
\hline NPL & $10.67 \%$ & $11.70 \%$ & $10.02 \%$ & $8.70 \%$ & $6.34 \%$ \\
\hline
\end{tabular}

Sumber: www.ojk.go.id, 2020

Pada Tabel 1. dan dapat dilihat bahwa rata-rata NPL BPR menunjukkan tren yang meningkat dan masih diatas ketentuan OJK sebesar 5\%. Studi terdahulu menemukan bahwa tingginya tingkat Non Performing Loan dapat disebabkan berbagai faktor diantaranya faktor internal dan faktor eksternal, (Djohanputro \& Kountur, 2007). Faktor internal NPL BPR meliputi (1) Proses pemberian kredit yang tidak sesuai prosedur. (2) Tidak terpenuhinya beberapa syarat pemberian kredit. (3) Proses penagihan yang tidak konsisten. (4) Pemberian kredit yang tidak berkelompok. (5) Intervensi pemilik BPR. (6) Kualitas sumber daya manusia yang rendah. Faktor eksternal meliputi : (1) Persaingan yang ketat. (2) Perburukan kondisi ekonomi secara global.

Nadham \& Nahid, (2015) menemukan bahwa faktor- faktor yang mempengaruhi NPL adalah (1) Tingkat suku bunga, (2) Pengawasan, (3) Kondisi ekonomi, dan (4) Gross Domestik Product atau tingkat penghasilan masyarakat. (Dewi, 2011) menemukan bahwa karyawan yang berkualitas dan pengawasan berpengaruh terhadap penurunan NPL. Dari sudut pandang teori keagenan (agency theory) terdapat hubungan antara agen yaitu direksi BPR dan principal yaitu pemilik BPR. Teori keagenan mengimplikasikan terdapat asimetri informasi antara pemilik dan agen sehingga untuk meminimalisir asimetri 
informasi tersebut dibutuhkan agency cost. Agency cost bisa dalam bentuk pengawasan atau pemberian imbalan pada si agen (Kurniawan, 2014).

Eric \& Assenso (2015) serta Dhar \& Bakshi (2015) menemukan bahwa NPL dipengaruhi oleh tingkat suku bunga yang tinggi dan penyaluran kredit kepada Sensitive Sector. (Dileep \& Rao, 2013) menemukan penyebab NPL ad alah adanya campur tangan pemerintah/politik. Fernando \& Dedunu (2017), Oladeebo \& Oladeebo (2008), Saleem, Jant, Khattak, \& Quraishi (2014), Ifeanyi, Nwachukwu, Alamba, \& Oko-Isu (2010), Angaine \& Waari (2014). Pada penelitian tersebut ditemukan bahwa NPL dipengaruhi oleh: (1) Jumlah penghasilan peminjam (2) Jumlah pinjaman (3) Latar belakang peminjam (4) Penjamin pinjaman (5) Tingkat pendidikan peminjam (6) Status pernikahan (7) Ukuran usaha nasabah (8) Jumlah angsuran (9) Umur peminjam (10) Jangka waktu kredit (11) Jumlah tanggungan (12) Hobi nasabah (13) Tipe usaha nasabah.

Secara sistematis model penelitian ini dapat dilihat pada Gambar 1. sebagai berikut :

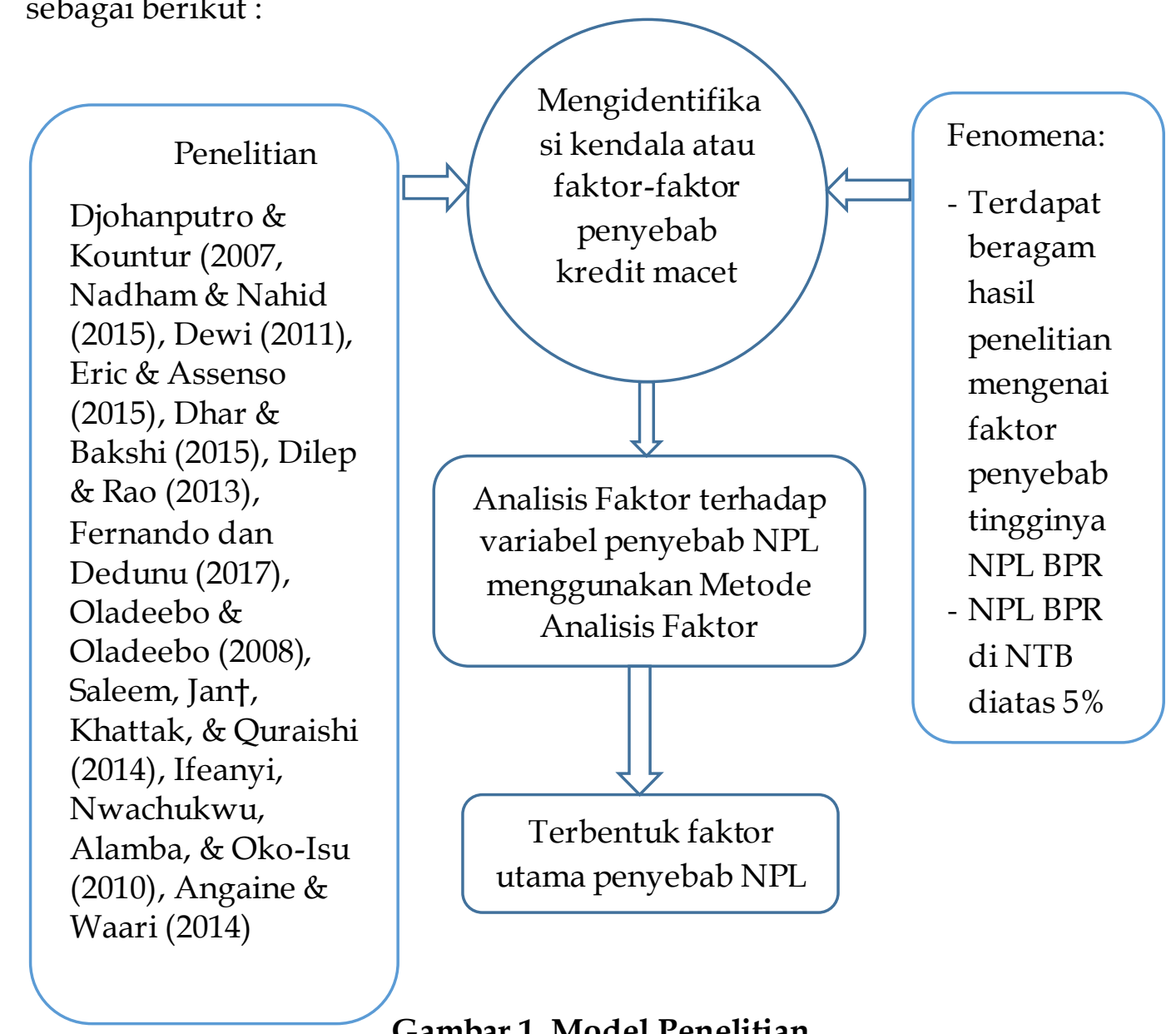

Sumber: Data Penelitian, 2020

Dari penelitian terdahulu ditemukan bahwa terdapat beragam faktor yang mempengaruhi NPL pada BPR atau lembaga keuangan yang bergerak dalam pembiayaan sektor mikro. Masing-masing peneliti menemukan penyebab yang berbeda diantara penelitian yang dilakukan. Penelitian ini mencoba 
memasukkan variabel penyebab NPL pada BPR yang ditemukan dari penelitian terdahulu kemudian dilakukan pengelompokan untuk mencari faktor utama penyebab NPL menggunakan metode analisis faktor.

Berdasarkan gap tersebut maka rumusan permasalahan dalam penelitian ini adalah apakah faktor-faktor utama penyebab NPL pada BPR di Nusa Tenggara Barat?. Berdasarkan rumusan masalah maka tujuan penelitian ini adalah untuk mengidentifikasi faktor-faktor utama yang mempengaruhi NPL BPR di Nusa Tenggara Barat.

Kerangka konseptual penelitian ini berangkat dari stakeholder theory dimana terdapat banyak pihak yang memiliki kepentingan terhadap keberadaan BPR diantaranya pemegang saham, manajemen, karyawan, nasabah, masyarakat dan Pemerintah dalam hal ini Otoritas Jasa keuangan (OJK). Stakeholder theory memberi petunjuk bahwa kelompok pemangku kepentingan yang berbeda akan memiliki pandangan yang berbeda tentang bagaimana dan untuk apa suatu organisasi melakukan suatu operasi (Hatta, 2012). Stakeholder Theory dapat menjelaskan dalam penelitian ini bahwa organisasi harus memperhatikan kepentingan semua pemangku kepentingan baik yang memiliki kepentingan langsung seperti debitur, shareholder, kreditur, dan pemerintah, serta pihak yang memiliki kepentingan tidak langsung seperti masyarakat, bank atau lembaga keuangan lainnya (kompetitor), pelaku UMKM, petani, pedagang dan pihak-pihak lainnya. Salah satu kepentingan stakeholder adalah terciptanya BPR yang sehat yang salah satu indikasi nya adalah angka NPL yang rendah.

\section{METODE PENELITIAN}

Jenis penelitian adalah kuantitatif. Penelitian ini menggunakan metode statistik analisis faktor dengan pendekatan Principle Component Analysis (PCA) dan termasuk Exploratory Factor Analysis (EFA). Penelitian ini dilakukan pada BPR dan BPRS yang ada di Propinsi Nusa Tenggara Barat. Waktu penelitian adalah antara bulan Juli sampai dengan Agustus 2019. Populasi penelitian ini adalah direksi dan karyawan bagian marketing dan bagian penagihan dari 32 BPR/BPRS di Propinsi NTB. Alasan pemilihan responden karena direksi, bagian marketing dan bagian penagihan yang terlibat langsung terhadap penyaluran kredit dan penanganan kredit bermasalah. Tabel 1. merupakan sebaran responden penelitian.

\section{Tabel 1. Responden Penelitian}

\begin{tabular}{lcl}
\hline \multicolumn{1}{c}{ Responden } & Jumlah & \multicolumn{1}{c}{ Keterangan } \\
\hline Direksi & 64 orang & $\begin{array}{l}\text { Minimal direksi pada BPR adalah2 orang sehinga } \\
\text { total direksi pada 32 BPR sebanyak64 orang }\end{array}$ \\
Bagian Marketing & 32 orang & $\begin{array}{l}\text { Dipilih satumarketing pada masing-masing BPR } \\
\text { Dipilih satu bagian penagihan pada masing- } \\
\text { Bagian Penagihan }\end{array}$ \\
32 orang & & \\
Total & 128 orang & \\
\hline
\end{tabular}

Sumber: Data Penelitian, 2020

Perancangan dan perumusan variabel dilakukan dengan 2 cara, yaitu pencarian literatur yaitu berdasarkan penelitian sebelumnya dan interview 
mendalam ke beberapa direksi dan komisaris BPR. Dari Hasil tahap pencarian diperoleh 38 variabel dengan rincian sebagai berikut:

Tabel 2. Variabel Faktor-Faktor Yang Menyebabkan NPL

\begin{tabular}{|c|c|c|}
\hline $\mathrm{NO}$ & $\begin{array}{l}\text { Indikator/Variabel Permasalahan } \\
\text { Pembentuk Faktor }\end{array}$ & Literatur/penelitiar \\
\hline 1 & $\begin{array}{l}\text { Sumber Daya Manusia baik kualitas } \\
\text { maupun kuantitas }\end{array}$ & $\begin{array}{l}\text { Djohanputro dan Kountur (2007), } \\
\text { Novira(2015), Dewi (2011) }\end{array}$ \\
\hline 2 & Keterbatasan tenaga analisis kredit & $\begin{array}{l}\text { Djohanputro dan Kountur (2007), } \\
\text { Novira(2015), Kariuki (2014) }\end{array}$ \\
\hline 3 & $\begin{array}{l}\text { Keterbatasan } \\
\text { collection }\end{array}$ & $\begin{array}{l}\text { Djohanputro dan Kountur (2007), } \\
\text { Novira(2015) }\end{array}$ \\
\hline 4 & $\begin{array}{l}\text { Pengcoveran nilaiagunan dibaw ah } \\
\text { nilai kredit }\end{array}$ & $\begin{array}{l}\text { Djohanputro dan Kountur (2007), } \\
\text { Fernando \& Dedunu (2017) }\end{array}$ \\
\hline 5 & $\begin{array}{l}\text { Analisis kredit yang tidak } \\
\text { menyeluruh }\end{array}$ & $\begin{array}{l}\text { Djohanputro dan Kountur (2007), } \\
\text { Kariuki(2014) }\end{array}$ \\
\hline 6 & $\begin{array}{l}\text { Pengikatan kredit bawah tangan } \\
\text { / tidaknotaril }\end{array}$ & $\begin{array}{l}\text { Novira(2015), Djohanputro dan Kountur } \\
\text { (2007), }\end{array}$ \\
\hline 7 & $\begin{array}{l}\text { Pembayaran angsuran secara } \\
\text { manual/bukan potong gaji }\end{array}$ & Djohanputro dan Kountur (2007) \\
\hline 8 & $\begin{array}{l}\text { an dari komisaris yang } \\
\text { tal }\end{array}$ & $\begin{array}{l}\text { tro dan Kountur (2007), } \\
\text { 15), Nadham \& Nahid (2015), }\end{array}$ \\
\hline 9 & $\begin{array}{l}\text { ang tidak memiliki latar } \\
\text { rbankan }\end{array}$ & Djohanputro dan Kountur (2007) \\
\hline 10 & $\begin{array}{l}\text { nasabah dari komisaris } \\
\text { pemilik }\end{array}$ & Djohanputro dan Kountur (2007) \\
\hline 11 & nya kunjungan rutin ke & Djohanputro dan Kountu \\
\hline 12 & h keberadaan tim internal & o dan Kountur (2007), Dewi \\
\hline 13 & & ntur (2007), \\
\hline 14 & sikan & $007)$ \\
\hline 15 & $\begin{array}{l}\text { i kredit pada } \\
\text { reuangan }\end{array}$ & Djohanputro dan Kountur (2007) \\
\hline 16 & $\begin{array}{l}\text { k memiliki hubungan dengan } \\
\text { h }\end{array}$ & Djohanputro dan Kountur (2007) \\
\hline 17 & $\begin{array}{l}\text { san yang lemah terhadap } \\
\text { g/ collection }\end{array}$ & $\begin{array}{l}\text { Djohanputro dan Kountur } \\
\text { Novira(2015) }\end{array}$ \\
\hline 18 & $\begin{array}{l}\text { trasi pembiayaan pada } \\
\text { tentu }\end{array}$ & Dilep dan Kesava (2013) \\
\hline 19 & n prosedur yang belum & Angaine and Waari (2014) \\
\hline 20 & & 015) \\
\hline 21 & spansi kredit dari kompetitor & (2014) \\
\hline 22 & $\begin{array}{l}\text { an rata-rata masyarakat } \\
\text { lah }\end{array}$ & $\begin{array}{l}\text { Fernando \& Dedunu } \\
\text { Nwachukwu, Alamba,and Oko-Isu } \\
(2010)\end{array}$ \\
\hline
\end{tabular}

Bersambung... 
Lanjutan Tabel3.

\begin{tabular}{|c|c|c|}
\hline 23 & $\begin{array}{l}\text { Adanya kebijakan/dorongan } \\
\text { pemerintah untukmembiayaisektor } \\
\text { tertentu }\end{array}$ & $\begin{array}{l}\text { Dilep dan Kesava (2013), Dhar \& Bakshi } \\
\text { (2015) }\end{array}$ \\
\hline 24 & Kegagalan usaha nasabah & Angaine and Waari (2014) \\
\hline 25 & $\begin{array}{l}\text { Campur tangan pemilik atas } \\
\text { penyaluran kredit }\end{array}$ & Djohanputro dan Kountur (2007) \\
\hline 26 & Penyaluran kredit berkelompok & Djohanputro dan Kountur (2007) \\
\hline 27 & $\begin{array}{l}\text { Tidak adanya petugas khusus dalam } \\
\text { penanganan kredit bermasalah }\end{array}$ & Djohanputro dan Kountur (2007) \\
\hline 28 & Sistem administrasi yang lemah & Angaine and Waari (2014) \\
\hline 29 & $\begin{array}{l}\text { Kebijakan perkreditan yang } \\
\text { expansive }\end{array}$ & Djohanputro dan Kountur (2007) \\
\hline 30 & Perubahan BI Rate / suku bunga & Mahmudah, (2013) \\
\hline 31 & $\begin{array}{l}\text { Permasalahan keluarga } \\
\text { nasabah(seperti status pernikahan, } \\
\text { kematian dll) }\end{array}$ & $\begin{array}{l}\text { Saleem, Jant, Khattak, \& Quraishi (2014) } \\
\text { Angaine and Waari (2014) }\end{array}$ \\
\hline 32 & $\begin{array}{l}\text { Musibah Bencana alam } \\
\text { Pemberian plafon kredityang tidak } \\
\text { sesuai kebutuhannasabah }\end{array}$ & $\begin{array}{l}\text { Novira (2013) } \\
\text { Nwachukwu, Alamba, and Oko-Isu } \\
\text { (2010) }\end{array}$ \\
\hline 34 & $\begin{array}{l}\text { Jangka waktu kredit yang terlalu } \\
\text { panjang } \\
\text { Konsentrasi penyaluran kreditpada } \\
\text { sekelompok debitur yang berisiko } \\
\text { tinggi }\end{array}$ & $\begin{array}{l}\text { Nwachukwu, Alamba, and Oko-Isu } \\
\text { (2010) } \\
\text { Dilep dan Kesava (2013) }\end{array}$ \\
\hline 36 & Karakter nasabah & $\begin{array}{l}\text { Oladeebo (2008), aleem, Jant, Khattak, \& } \\
\text { Quraishi (2014), Kariuki (2014) } \\
\text { Oladeebo (2008), aleem, Jant, Khattak, \& }\end{array}$ \\
\hline 37 & Pendidikannasabah & $\begin{array}{l}\text { Quraishi (2014), Nwachukwu, } \\
\text { Alamba,and Oko-Isu (2010), Angaine } \\
\text { and Waari (2014) } \\
\text { Oladeebo (2008), aleem, Jant, Khattak, \& }\end{array}$ \\
\hline 38 & Pengalaman usaha nasabah & Quraishi (2014) \\
\hline
\end{tabular}

Sumber: Data Penelitian, 2020

Instrumen utama dalam penelitian ini adalah angket atau kuesioner yang pertanyaannya dirumuskan dalam 38 variabel yang diadopsi dan dimodifikasi dari penelitian Djohanputro \& Kountur (2007) dan penelitian Rahman (2018). Penelitian ini menggunakan data kuantitatif jenis data ordinal dengan menggunakan skala likert dimana nilai intensitasnya dari 1 sampai 5. Teknik analisis data yang digunakan adalah analisis faktor menggunakan pendekatan Principle Component Analysis (PCA) dimana akan terbentuk beberapa faktor berupa variabel laten yang belum dapat ditentukan sebelum analisis dilakukan. Beberapa tahap yang dilalui diantaranya (Santoso, 2016:63) Tahap pertama menilai Variabel melaui pengujian KMO dan Barlett' test.

Tahap ke dua Proses Factoring dan rotasi dengan pendekatan varimax analisis didekati dengan: Komunalitas (communalities), Total Variance explained, Component Matrix dan rotasi Component Matrix, Interpretasi variabel. 


\section{HASIL DAN PEMBAHASAN}

Data yang digunakan dalam penelitian ini adalah data primer. Pengumpulan data dilakukan dengan penyebaran kuesioner kepada responden. Kuesioner yang disebarkan sebanyak 128 exemplar dan yang kembali sebanyak 102 exemplar (sebanyak $80 \%$ ). Hasil analisis faktor exploratory terhadap 38 variabel adalah sebagai berikut:Tahap pertama adalah menilai variabel. Penilaian variabel dilakukan dengan melakukan Uji KMO dan Bartlett's test. Jika hasil uji KMO dan Bartlett's test. > 0.5 menunjukkan sampel dapat dianalisis lebih lanjut. Tabel 3. adalah hasil uji KMO dan Bartlett's.

Tabel 3. KMO dan Bartlett's Test

Kaiser-Meyer-Olkin Measure of Sampling Adequacy.

0.785

\section{Sumber: Data Penelitian, 2020}

Berdasarkan Tabel 3. Angka KMO dan Bartlett's Test sebesar 0.785 yang mana angka tersebut $>0.5$ sehingga berdasarkan hasil uji KMO dan Barlett' test menunjukkan sampel dapat dianalisis lebih lanjut.

Tahap kedua, proses faktoring dan rotasi. Proses faktoring yaitu menentukan jumlah faktor yang terbentuk. Analisis yang dilakukan pada tahapan ini adalah: (1) Communalities, Variabel dianggap mampu menjelaskan faktor jika nilai extraction untuk semua variabel adalah lebih besar dari 0.5.

\section{Tabel 4. Nilai Communalities}

\begin{tabular}{llllll}
\hline 1 & 1 & 0.624 & 20 & 1 & 0.639 \\
2 & 1 & 0.69 & 21 & 1 & 0.856 \\
3 & 1 & 0.75 & 22 & 1 & 0.566 \\
4 & 1 & 0.879 & 23 & 1 & 0.793 \\
5 & 1 & 0.723 & 24 & 1 & 0.828 \\
6 & 1 & 0.86 & 25 & 1 & 0.699 \\
7 & 1 & 0.56 & 26 & 1 & 0.775 \\
8 & 1 & 0.743 & 27 & 1 & 0.727 \\
9 & 1 & 0.655 & 28 & 1 & 0.53 \\
10 & 1 & 0.86 & 29 & 1 & 0.805 \\
12 & 1 & 0.712 & 30 & 1 & 0.681 \\
13 & 1 & 0.733 & 31 & 1 & 0.8 \\
14 & 1 & 0.835 & 33 & 1 & 0.744 \\
15 & 1 & 0.665 & 34 & 1 & 0.766 \\
16 & 1 & 0.791 & 36 & 1 & 0.637 \\
17 & 1 & 0.695 & 37 & 1 & 0.75 \\
18 & 1 & 0.848 & 38 & 1 & 0.764 \\
19 & 1 & 0.639 & & & \\
\hline
\end{tabular}

Sumber: Data Penelitian, 2020

Berdasarkan Tabel 4. nilai extraction semua variabel adalah diatas 0.5 sehingga variabel dianggap mampu menjelaskan faktor. (2) Total variance Explained, menunjukkan nilai masing-masing variabel yang dianalisis. Tabel 6 menunjukkan nilai total variance explained.

Berdasarkan Tabel 5. initial eigenvalue yang terbentuk adalah sebanyak 10 faktor, hal ini didasarkan bahwa syarat untuk menjadi faktor adalah nilai total 
eigenvalues $1(>1)$,sehingga berdasarkan hasil tes maka faktor yang terbentuk sebanyak 10.

Tabel 5. Total Variance Explained

\begin{tabular}{|c|c|c|c|c|c|c|c|}
\hline \multirow[b]{2}{*}{ Component } & \multicolumn{3}{|c|}{ Initial Eigenvalues } & \multicolumn{3}{|c|}{$\begin{array}{c}\text { Extraction Sums of Squared } \\
\text { Loadings }\end{array}$} & \multirow{2}{*}{ 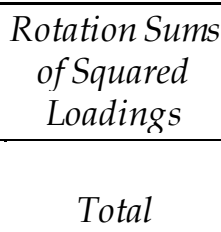 } \\
\hline & Total & $\begin{array}{c}\text { \% of } \\
\text { Variance }\end{array}$ & $\begin{array}{c}\text { Cumulative } \\
\%\end{array}$ & Total & $\begin{array}{c}\% \text { of } \\
\text { Variance }\end{array}$ & $\begin{array}{c}\text { Cumulative } \\
\%\end{array}$ & \\
\hline 1 & 10.388 & 29.680 & 29.680 & 10.388 & 29.680 & 29.680 & 3.811 \\
\hline 2 & 2.523 & 7.210 & 36.889 & 2.523 & 7.210 & 36.889 & 6.092 \\
\hline 3 & 2.343 & 6.694 & 43.584 & 2.343 & 6.694 & 43.584 & 5.651 \\
\hline 4 & 2.072 & 5.920 & 49.504 & 2.072 & 5.920 & 49.504 & 4.586 \\
\hline 5 & 1.614 & 4.612 & 54.116 & 1.614 & 4.612 & 54.116 & 2.653 \\
\hline 6 & 1.605 & 4.586 & 58.703 & 1.605 & 4.586 & 58.703 & 1.846 \\
\hline 7 & 1.408 & 4.023 & 62.725 & 1.408 & 4.023 & 62.725 & 2.814 \\
\hline 8 & 1.326 & 3.788 & 66.513 & 1.326 & 3.788 & 66.513 & 1.595 \\
\hline 9 & 1.178 & 3.365 & 69.877 & 1.178 & 3.365 & 69.877 & 4.978 \\
\hline 10 & 1.034 & 2.954 & 72.831 & 1.034 & 2.954 & 72.831 & 2.966 \\
\hline
\end{tabular}

Sumber: Data Penelitian, 2020

Tahap ke 3 adalah component matrix, menunjukkan nilai korelasi antara masing-masing variabel dengan faktor yang terbentuk. Pada tabel 7 terlihat bahwa 38 variabel (X1 s.d X38) memiliki hubungan atau korelasi dengan faktor baru yang telah terbentuk.

Tabel 6. Component Matrix

\begin{tabular}{|c|c|c|c|c|c|c|c|c|c|c|}
\hline & 1 & 2 & 3 & 4 & 5 & 6 & 7 & 8 & 9 & 10 \\
\hline 10 & .741 & & -.543 & & & & & & & \\
\hline 23 & .710 & & -.475 & & & & & & & \\
\hline 15 & .688 & & & & & & & & & \\
\hline 17 & .687. & & & & & & & & & \\
\hline 14 & .686 & -.512 & & & & & & & & \\
\hline 16 & .675 & & -.552 & & & & & & & \\
\hline 12 & .660 & & & & & & & & & \\
\hline 28 & .656 & -.528 & & & & & & & & \\
\hline 5 & .648 & & & & & & & & & \\
\hline 22 & .640. & & & & & & & & & \\
\hline 4 & .623 & -.560 & & & & & & & & \\
\hline 6 & .618 & -.546 & & & & & & & & \\
\hline 18 & .614 & & -.564 & & & & & & & \\
\hline 29 & .608 & & & & & & & & & \\
\hline 20 & .604 & & & -.401 & & & & & .445 & \\
\hline 25 & .593 & & -.413 & & & & & & & \\
\hline 33 & .592 & & & .423 & & & & & & \\
\hline 7 & .585 & & & & & & & & & \\
\hline 21 & .583 & & & & & & & & & \\
\hline 31 & .552 & & & & & & & & & \\
\hline 9 & .539 & & & & & & & & & \\
\hline
\end{tabular}


Lanjutan Tabel 6.

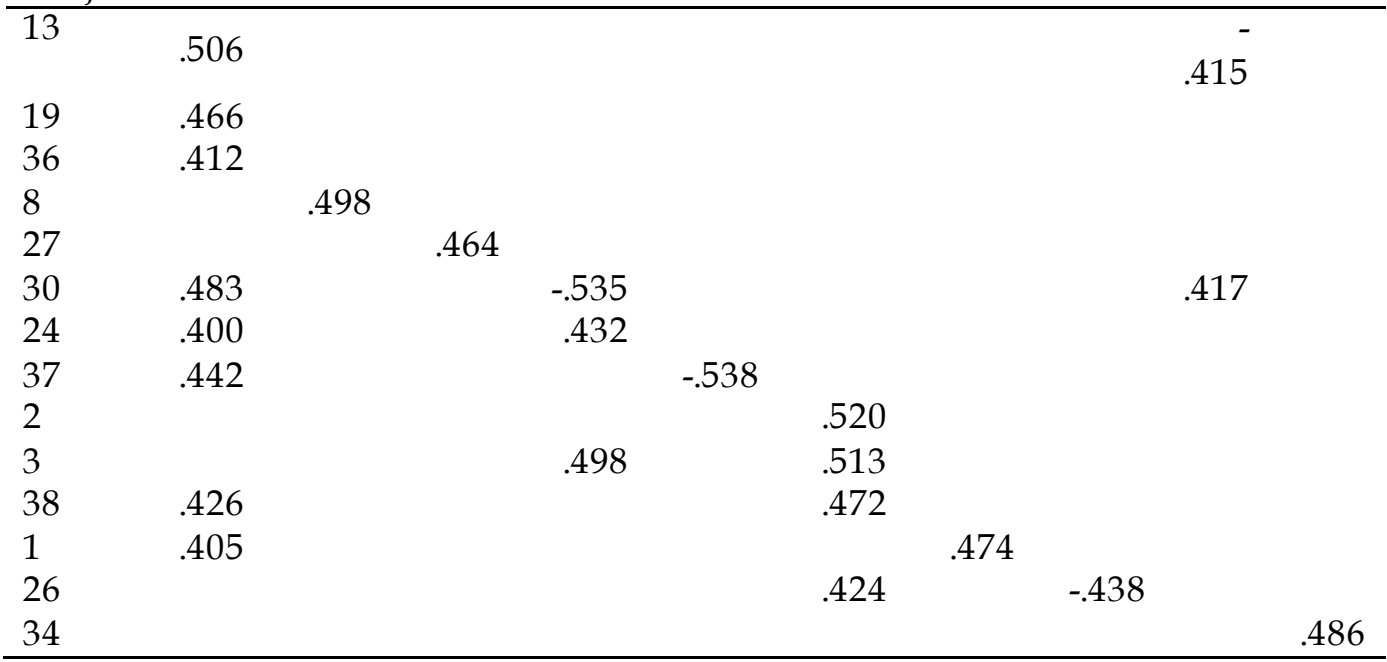

Sumber: Data Penelitian, 2020

Tahap ke 4 adalah rotasi, menunjukkan distribusi variabel yang lebih jelas dan nyata. Pada proses rotasi, angka factor loading yang awalnya kecil semakin diperkecil dan factor loading yang besar semakin diperbesar. Inilah kegunaan proses rotasi, yakni memperjelas posisi sebuah variabel pada sebuah faktor. Berdasarkan Tabel 7. dapat digambarkan bahwa variabel berkelompok menjadi 10 faktor.

\section{Tabel 7. Pattern Matrix}

\begin{tabular}{|c|c|c|c|c|c|c|c|c|c|c|}
\hline & 1 & 2 & 3 & 4 & 5 & 6 & 7 & 8 & 9 & 10 \\
\hline 18 & 0.868 & & & & & & & & & \\
\hline 10 & 0.849 & & & & & & & & & \\
\hline 16 & 0.822 & & & & & & & & & \\
\hline 23 & 0.772 & & & & & & & & & \\
\hline 25 & 0.679 & & & & & & & & & \\
\hline 4 & & 0.883 & & & & & & & & \\
\hline 6 & & 0.879 & & & & & & & & \\
\hline 14 & & 0.86 & & & & & & & & \\
\hline 28 & & 0.803 & & & & & & & & \\
\hline 30 & & & 0.869 & & & & & & & \\
\hline 20 & & & 0.795 & & & & & & & \\
\hline 19 & & & 0.533 & & & & & & & \\
\hline 32 & & & & 0.745 & & & & & & \\
\hline 33 & & & & 0.668 & & & & & & \\
\hline 24 & & & & 0.64 & & & & & & \\
\hline 5 & & & & 0.549 & & & & & & \\
\hline 36 & & & & & 0.682 & & & & & \\
\hline 11 & & & & & 0.652 & & & & & \\
\hline 31 & & & & & 0.629 & & & & & \\
\hline
\end{tabular}

Bersambung... 
Lanjutan Tabel 7.

\begin{tabular}{llllll}
\hline 37 & 0.868 & & & & \\
22 & 0.742 & & & & \\
8 & & 0.794 & & & \\
9 & & 0.76 & & & \\
13 & & & 0.741 & & \\
21 & & 0.622 & & \\
1 & & & 0.717 & \\
7 & & & 0.545 & \\
2 & & & & 0.816 \\
38 & & & & & 0.561 \\
\hline
\end{tabular}

Sumber: Data Penelitian, 2020

Setelah dilakukan rotasi faktor, langkah selanjutnya adalah penentuan signifikansi nilai faktor loading untuk menentukan pengelompokan variabel ke dalam faktor yang sesuai. Nilai faktor loading sebesar 0.5 telah dianggap signifikan untuk ukuran sample dibawah 200 dengan demikian maka analis faktor dapat di interpretasi.

Tahap terakhir dari analis faktor adalah interpretasi atas faktor yang terbentuk. Tabel 8. menunjukkan interpretasi dari faktor. Berikut adalah interpretasi atas variabel yang terbentuk.

Tabel 8. Interpretasi Variabel

\begin{tabular}{|c|c|c|}
\hline Nama Faktor & \multicolumn{2}{|c|}{ Item pertanyaan } \\
\hline \multirow{5}{*}{$\begin{array}{l}\text { Tekanan dari } \\
\text { pemegang saham }\end{array}$} & 18 & Konsenstrasi pembiayaan pada sektor tertentu \\
\hline & 10 & Referensi nasabah dari komisaris maupun pemilik \\
\hline & 16 & Pemilik memiliki hubungan dengan nasabah \\
\hline & 23 & $\begin{array}{l}\text { Adanya kebijakan/dorongan pemerintah } \\
\text { membiayai sektor tertentu }\end{array}$ \\
\hline & 25 & Campur tangan pemilik a tas penyaluran kredit \\
\hline \multirow{4}{*}{$\begin{array}{l}\text { Pengcoveran } \\
\text { jaminan yang tidak } \\
\text { memadai }\end{array}$} & 4 & Pengcoveran nilaiagunan dibawah nilai kredit \\
\hline & 6 & Pengikatan kredit bawah tangan / tidak notaril \\
\hline & 14 & Kredit yang tidak diasuransikan \\
\hline & 28 & Sistemadministrasi yang lemah \\
\hline \multirow[t]{3}{*}{ Fluktuasi bunga } & 30 & Perubahan BIRate / suku bunga \\
\hline & 20 & Kenaikan sukubunga \\
\hline & 19 & Standar dan prosedure yang belum memadai \\
\hline \multirow{4}{*}{$\begin{array}{l}\text { Musibah } \\
\text { dihadapi } \\
\text { nasabah }\end{array}$} & 32 & Musibah Bencana alam \\
\hline & 33 & $\begin{array}{l}\text { Pemberian plafon kredit yang tidak sesuai kebutuhan } \\
\text { nasabah }\end{array}$ \\
\hline & 24 & Kegagalan usaha nasabah \\
\hline & 5 & Campur tangan pemilik atas penyaluran kredit \\
\hline \multirow[t]{3}{*}{ Kondisinasabah } & 36 & Karakter nasabah \\
\hline & 11 & Kurangnya kunjungan rutin ke nasabah \\
\hline & 31 & $\begin{array}{l}\text { Permasalahan keluarga nasabah(seperti status pernikahan, } \\
\text { kematian dll) }\end{array}$ \\
\hline
\end{tabular}

Bersambung ... 
Lanjutan Tabel 8.

\begin{tabular}{|c|c|c|}
\hline Pendidikan & 37 & Pendidikannasabah \\
\hline $\begin{array}{l}\text { penghasilan } \\
\text { nasabah }\end{array}$ & 22 & Pendapatan rata-rata masyarakat yang rendah \\
\hline Pengawasan dari & 8 & Pengawasan dari komisaris yang tidak optimal \\
\hline komisaris & & Komisaris yang tidak memiliki latar belakang perbankan \\
\hline & 9 & \\
\hline Persaingan usaha & 13 & Persaingan usaha yang ketat \\
\hline & 21 & Ekspansi kredit dari kompetitor \\
\hline Sumber & 1 & Sumber Daya Manuasia \\
\hline manusia & 7 & Pembayaran angsuran secara manual/bukan potong gaji \\
\hline Keterbatasan & 2 & Keterbatasan tenaga analisis kredit \\
\hline & 38 & Pengalaman usaha nasabah \\
\hline
\end{tabular}
Sumber: Data Penelitian, 2020

Berdasarkan Tabel 8. tingginya NPL BPR di Propinsi Nusa Tenggara Barat dapat diterangkan oleh 10 faktor dengan rincian: (1) Tekanan dari pemegang saham. (2) Jaminan yang tidak memadai.(3) Perubahan bunga. (4) Musibah yang dihadapi oleh nasabah. (5) Kondisi nasabah. (6) Pendidikan dan penghasilan nasabah. (7) Pengawasan. (8) Persaingan usaha. (9) Sumber daya manusia. (10) Keterbatasan analisis kredit. Dari 10 faktor yang ditemukan terdapat 5 faktor utama yang bersumber dari internal BPR yaitu: Tekanan dari pemegang saham, Jaminan yang tidak memadai, Pengawasan, Sumber daya manusia, Keterbatasan analisis kredit. Terdapat 5 faktor eksternal penyebab NPL diantaranya: Perubahan Bunga, Musibah yang dihadapi oleh nasabah, Kondisi nasabah, Pendidikan dan penghasilan nasabah, Persaingan usaha.

Temuan dalam penelitian ini dapat memperjelas konsep stakeholder theory. Berdasarkan stakeholder theory, terdapat beberapa pihak yang memiliki kepentingan terhadap BPR diantaranya: Pemerintah, Pemegang Saham, Otoritas Jasa Keuangan (OJK), Nasabah Peminjam, Nasabah Deposan, dan masyarakat yang memiliki kepentingan atas terciptanya BOPR yang sehat dengan salah satu indikator tingkat NPL yang rendah. Temuan dari penelitian ini dapat dijadikan acuan oleh BPR/BPRS dalam rangka penanganan kredit bermasalah yang ada di BPR/BPRS, sehingga penyelesaian kredit bermasalah dapat dilakukan dengan tepat dam memberikan dampak signifikan bagi perbaikan kinerja BPR khususnya kinerja NPL.

\section{SIMPULAN}

Berdasarkan hasil analisis faktor exploratory diperoleh 10 faktor utama yang menjadi penyebab tingginya NPL pada BPR di Nusa Tenggara Barat yang terdiri dari faktor internal dan eksternal BPR. Faktor tersebut adalah: Tekanan dari pemegang saham, Jaminan yang tidak memadai, Perubahan bunga, Musibah yang dihadapi oleh nasabah. Kondisi nasabah. Pendidikan dan penghasilan nasabah. Pengawasan, Persaingan usaha, Sumber daya manusia dan Keterbatasan analisis kredit. 
Dari hasil penelitian, maka dapat disarankan: (1) Bagi BPR, dalam upaya menekan jumlah NPL pada masing-masing BPR hendaklah diutamakan menekan faktor penyebab NPL yang bersumber dari internal BPR. Hal ini dikarenakan faktor internal merupakan faktor atau kondisi yang dapat dikendalikan oleh BPR. Untuk menekan faktor penyebab NPL dari sisi eksternal maka diharapkan BPR dapat membuat langkah-langkah mitigasi, seper ti untuk mengantisipasi ketatnya persaingan dapat dilakukan dengan meningkatkan loyalitas nasabah. Untuk mengantisipasi perubahan bunga dapat dilakukan oleh BPR adalah dengan melonggarkan ratio installment to income (RITI).Untuk musibah yang dihadapi oleh nasabah seperti kegagalan usaha langkah antisipasi yang dapat dilakukan adalah dengan melakukan kunjungan rutin ke nasabah sehingga dapat dilakukan langkah antisipasi lebih awal jika terdapat penurunan pendapatan usaha nasabah. Upaya menekan jumlah NPL ini sangat penting dilakukan oleh BPR untuk meningkatkan kepercayan para stakeholder terha dap BPR, yang mana hal ini sejalan dengan stakeholder theory. (2) Untuk OJK selaku pengawas hasil penelitian ini dapat dijadikan acuan untuk meningkatkan pengawasan terhadap BPR sesuai dengan faktor utama penyebab NPL pada BPR.

Saran untuk penelitian mendatang adalah (1) Kuesioner dalam penelitian ini berupa pertanyaan tertutup sehingga tidak dapat mengetahui alasan responden memilih jawaban tersebut. Saran untuk penelitian selanjutnya adalah menyediakan pertanyaan yang bersifat terbuka pada kuesioner sehingga dapat diketahui alasan responden dalam memilih jawaban yang disediakan oleh peneliti. (2) Penelitian hanya dilakukan pada BPR yang memberikan kredit kepada sektor UMKM. Untuk ke depan penelitian dapat dikembangkan pada Bank umum baik itu BUMN, Swasta dan BUMD yang memiliki kompleksitas yang lebih tinggi dalam penanganan kredit bermasalah. (3) Jumlah responden hanya terbatas pada Direksi, Marketing dan Bagian penagihan yang merupakan tim utama yang berkaitan dengan penyaluran kredit. Untuk ke depan dapat menambahkan pihak-pihak yang merasakan dampak dari kenaikan NPL seperti komisaris BPR, OJK selaku pengawas BPR serta nasabah selaku pihak yang menerima kredit dari BPR

\section{REFERENSI}

Angaine, F., \& Waari, D. N. (2014). Factors Influencing Loan Repayment in MicroFinance Institutions in Kenya. IOSR Journal of Business and Management, 16(9), 66-72.

Dewi, O. L. K. (2011). Pengaruh Efektivitas Sistem Pengendalian Intern Terhadap Kualitas Kredit Bank Perkreditan Rakyat (BPR) Di Kota Pati. Universitas Diponegoro.

Dhar, S., \& Bakshi, A. (2015). Determinants of loan losses of Indian banks: A panel study. Journal of Asia Business Studies, 9(1), 17-32.

Dileep, \& Rao, G. V. K. (2013). A Study on Indian Rural Banking Industry: Issues and Challenges. Asia Pacific Journal of Research, 2(4), 1-13.

Djohanputro, B., \& Kountur, R. (2007). Non Performing Loan (NPL) Bank Perkreditan Rakyat (BPR) (Vol. 1). 
Eric, O., \& Assenso, J. K. (2015). Regulatory capital and its effect on credit growth, non-performing loans and bank efficiencyEvidence from Ghana. Jurnal Of Financial Economic Policy, 7(1), 401-420.

Fernando, A. A. J., \& Dedunu, H. H. (2017). Factors Affecting to Performing and Non- performing Borrower' s Loan Repayment Ability. Imperial Journal of Interdiciplinary, 3(9), 161-166.

Hatta, A. J. (2012). Faktor-Faktor Yang Mempengaruhi Kebijakan deviden: investigasi pengaruh Teori stakeholder. JAAI, 6(2), 1-22.

Herri, SE., MBA., P. (2008). Studi Peningkatan Peran Bank Perkreditan Rakyat (BPR) Dalam Pembiayaan Usaha Mikro Kecil (UMK) Di Sumatera Barat. Jurnal CBR UNAND BPR,1-37.

Ifeanyi, N., Nwachukwu, C., Alamba, S., \& Oko-Isu, A. (2010). Determinants of institutional credit repayment performance among farmers in afikpo north lga of ebonyi state, nigeria. Advances in Agriculture $\mathcal{E}$ Botanics- International Journal of the Bioflux Society, 2(3), 279-284.

Kurniawan, Y. (2014). Pengaruh Faktor Internal dan Eksternal Perusahaan terhadap Audit Delay dan Timeliness (studi Empiris pada Perusahaan Manufaktur yang terdaftar di Bursa Efek Indonesia Tahun 2012-2013. Universitas Diponegoro.

Mahmudah, R. (2013). Analisis Faktor-Faktor Yang Mempengaruhi NonPerforming Loan Di Sulawesi Selatan. Universitas Hasanuddin.

Nadham, V., \& Nahid, B. (2015). Determinants of Non Performing Loans in Commercial Banks. International Journal of Finance $\mathcal{E}$ Banking Studies (2147-

Oladeebo, J. O., \& Oladeebo, O. E. (2008). Determinants of Loan Repayment among Smallholder Farmers in Ogbomoso Agricultural Zone of Oyo State, Nigeria. Journal of Social Sciences, 17(1), 59-62.

Rahman, L. M. H. (2018). Analisis Faktor Kendala Implementasi Pola Pengelolaan Keuangan Badan Layanan Umum Daerah (PPK-BLUD) Puskesmas Di Kabupaten Lombok Barat. Universitas Mataram.

Saleem, A., Jant, D. F. A., Khattak, R. M., \& Quraishi, M. I. (2014). Impact of Farm and Farmers Characteristics On Repayment of Agriculture Credit (A case study of D.I.Khan, Khyber Pakhtoonkhawa. Abasyn Journal of Social Sciences, 4(1), 23-35.

Santoso, S. (2016). Aplikasi SPSS Pada Statistik Multivariat. Jakarta: Media Computindo. 